\title{
ANALYSIS OF APPLYING SONG MEDIA IN ENGLISH LEARNING OF ELEMENTARY SCHOOL AT THIRD GRADE STUDENTS IN SDN CIBEBER 1 CIMAHI
}

\author{
Wina Herliana $^{1}$, Eka Deti Daniawati ${ }^{2}$, Sudiyono. $^{3}$ \\ ${ }^{1}$ IKIP SILIWANGI \\ ${ }^{2}$ IKIP SILIWANGI \\ ${ }^{3}$ IKIP SILIWANGI \\ ${ }^{1}$ winaherlianaa06@gmail.com, ${ }^{2}$ daniawati.eka96@ gmail.com, ${ }^{3}$ sudiyonostkipslw@gmail.com
}

\begin{abstract}
In the learning of English language at school there are many ways can be done by teachers, including in using of tools or props and media can be appropriate to the level and level of education available. For learning English at level of basic education there are a number of learning that can be used as alternatives, one of which is the song media. This article discussed about steps of implementation song media of elementary school at Cibeber 1 Cimahi. Analysis of the problems used as research materials using descriptive qualitative analysis, while the focus of the object of observation is the steps of media song implementation in the school mention above. From the result of observation and analysis conducted by the autors, it is known that there is still incompatibility in the steps of media song. Implementation conducted by teacher with the steps implementation of instructional media as recommended by the experts of English education, especially experts who deepen the problem of media implementation song in learning English at school.
\end{abstract}

Keywords: Media, Song, Implementation

\section{INTRODUCTION}

One of the way for expedite to deliver English language in elementary school is helping such media. The media that can be applied to reach the purpose of learning there is media song. With used this song media the student be able to more understanding the material easily. And can help the teacher for learning prosess. In an empirical can be known that the results of teaching activities with aids is better than in with a manual.

The focus of this article is to know of implementation or steps applaying song media in teaching English language that is used in Elementary School at third grade students in SDN Cibeber 1 Cimahi.

The writers choose the school because the teacher has been taught the song media for learning English, so the writers see if learning using the song media is still suitable to apply in the classroom and to know whether already in accorodance with the framework of thinking referring to the experts. This article used qualitative design through observation to the school for analysis the teacher apply media song in the class with a race of experts. In our topic is 
suitable used technique analysis because we want to know in the school have enough appropriate used in their school.

Learning is an integral process among students, teachers and subjects. It can be happening everyday and everywhere. The sign existence on learning is change of behavior itself that happened by knowledge, skill, and attitude. Learning is a process of effort by an individual to obtain a change of behavior as whole as an outcome of the individual's own experience in interaction with environments(Uno, 2006). Language learning is synonymous with formal knowledge of a language, or explicit learning or the process which involves trial-and-error (Kaswan, \& Suprijadi, 2014). In formal learning, English is a special skill that cannot be done by anyone, without special skill instruction.

Language teaching is important to teach second-language, it also gives general overview about educational unit of language. Teaching learning process is very important, especially in Language learning. Teaching Language learning can be ongoing better or more produce when to help with Media. According to Shin (Ratminingsih, 2014) give expression that one of way to increase students' attention and involvement in learning activity needed media that use in learning. By usage media, it will help to learn language more understood.

Media is derived from Latin word "medium" that means "between". The term refers to anything that carries information between a source and receiver. In general, it is a mean of communication. Media is also considered as instructional system of teaching learning process. The media are important shapers of our perceptions and ideas. The media is constantly changing, expanding and developing, frequently in the direction of an increasingly sophisticated management of their audiences, but sometimes in ways which open out more democratic possibilities. Muchtar and Iskandar (Janah, 2016) explains that the tools for a learning event are very effective for the achievement of learning objective. Gerlach \& Ely (1971 in Janah, 2016: 4) said that the media when understood in broad outline is a human, material, or event that builds conditions that enable students to acquire knowledge, skills or attitudes.

There are several types of media; First graphic media such as pictures, photographs, graphs, charts or diagrams, posters, cartoons, comics etc. Second, three-dimensional media in the form of models such as solid model, cross-section model stacking model, work model, mock diorama etc. Third, audio and visual aids such as video, sound, films, song and others. The fourth, use of the environment as a medium of instruction (Sudjana, N., \& Rivai, 2015).

In producing optimal result of learning English by using media of song, it needs the correct understanding or great to step or way of implementing media. This paper will discuss the analysis of the steps or stages of media songs implementation at the Elementary School education unit.

Song is an alternative medium to facilitate language learning. According to Miranti, Engliana, and Hapsari (2015:169 in Wijayanti, 2016:135-136).

1. Through the song will motivate the child to enjoy learning more.

2. By singing children become happy and easier in understanding the teaching materials that are delivered. The ability of teachers in choosing songs and creating a movement appropriate to the age of development of children will also affect the success of the process of learning in early childhood.

3. Through varied songs and learning activities, educators can foster children's interest to be happy and active learning, even can facilitate children in understanding the teaching materials that are delivered. 
4. Children are made happy, not bored, and interested in following the learning process. Thus singing is an activity that children love very much.

The focus analysis of this article is steps of applying media song in teaching English language at the Elementary School at third grade students in SDN Cibeber 1 Cimahi. The Goal of this article is to know the steps of applying song media in Elementary School at third grade students in SDN Cibeber 1 Cimahi.

\section{Language Learning and Teaching}

Good \& Brophy (Uno, 2006) learning is a process or interaction that did by someone in acquire something new within behavior as a result from experience itself. Learning is knowing about a language. It is a process of effort by an individual to obtain a change of behavior as whole as a result of the individual's own experience in interaction with environments(Uno, 2006). Language learning is synonymous with formal knowledge of a language, or explicit learning or the process which involves trial-and-error (Kaswan, \& Suprijadi, 2014).

Language teaching is the essential research resource for language professionals providing a rich and expert overview of research in the field of second-language teaching and learning. Teaching English to children, in this case is the primary school students, should be different from teaching English to adult. It is because young children do not have specific foreign language needs, although some may be under pressure, usually from their parents or the school system, to pass the English examinations. There are some reasons of teaching English in the primary schools. According to Brewster \& Ellis (2004:27) in (Rahmawati, 2013) give a reason of starting to learn a foreign language several years earlier. It was simply to increase the total number of years spent learning the language. Language teaching needs good and interesting media.

\section{Media and Song Media}

Media used in the teaching learning activity will keep the learner focus on the teacher, thus the classroom will be on teacher's control. Teaching language can be efficient if we used media. According to Gerlach \& Ely (1971) in (Janah, 2016) said that the media when understood in broad outline is a human, material, or event that builds conditions that enable students to acquire knowledge, skills or attitudes. It means that media is tools to help teacher more creativity in deliver the materials more clearly and the real object for to reach the goal.

There are several types of media First graphic media such as pictures, photographs, graphs, charts or diagrams, posters, cartoons, comics etc. Second, three-dimensional media in the form of models such as solid model, cross-section model stacking model, work model, mock diorama etc. Third, audio and visual aids such as video, sound, films, song and others. The fourth, use of the environment as a medium of instruction (Sudjana, N., \& Rivai, 2015).

Using songs as tools for teaching a foreign language has many benefits. According to Lo and Li (1998) in (Keskin, 2011), songs are able to change the monotonous mood in the class and with the smoothing effect of music; they provide a comfortable class environment so that students can develop their lingual skills more easily.

\section{The Benefit of Media Song}


As for the advantages of the media song according to Brewster (2002) in (Nurhayati, 2002, pp. 6-7) song also enable the occurrence of language repetition naturally and fun. Songs can be used to develop all language skills in an integrative manner.

The song is an excellent "tool: to help students learn English, more specifically the song is believed to be able to motivate students during the English language learning. Can also be said that the song is an important part of learning English because the song makes students more sensitive to sounds and learn new vocabulary.

Various types of songs that we can use according to our needs in class. Songs can be categorized into activity song, animal song, counting song, food song, learning song, lullaby, patriot song, parody, sport song, traditional song and so on.

\section{Steps of Applying Song Media}

The analysis doing from research design as for write to do research. The steps analysis is first, the research question based on topic, second make research design, third to define steps observation, fourth do observation, then the result observation evaluation and the last conclusion and suggestion. This is the point steps song media that we used to analysis, Brewster (2007) (Ratminingsih, 2014, p. 597) states that the song is an ideal strategy to learn the language, because in the song there are repetitions of vocabulary and language structure and rhythm that can increase student interest in learning. The song comes from a written work that is played to the accompaniment of music. The use of songs widely used by teacher because the song is seen as effective as a medium of learning. According to Haycraft (1983:39) in (Febriati, 2014) the procedure of applying English songs are as follows: (1) Play the song as any ties as necessary and ask questions. (2) Show the students the script and get the class to sing it following the song. (3) Divide up the class and have a group, each singing a line. Replay the song often as necessary find out who has good voice try to get solos. (4) Bring out the students to conduct different combinations until the song is familiar, so it makes students can catch the words in the song. (5) Play and sing whenever you want to revise. It is a good idea to play song at the beginning of class while everyone is setting down.

According to Brewster (2002) in (Nurhayati, 2002) before using the song to teach its god we noted some of the following related framework song use for teaching language.

Create context; Teach first the vocabulary that is considered important by using tools; Listen to cassettes or song so students can listen; Do listening activities continued; Note pronunciation e.g identity patters of intonation, stressful words or syllables; Invite students to listen and repeat and practice; Give note written text song. Teachers can fill it into interesting activities and learning-oriented; Invite students to compare it type with similar types in their mother tongue, or nationally; Display them together, individually, in groups, in pairs.

Shin and Crandall (2014) in (Shin, 2014) suggest steps teachers can use after introducing children to the songs through video, audio, or singing themselves. Teaching Songs Step-byStep Introduce the topic of the song; Review the vocabulary students already know; Pre-teach the new vocabulary; Listen to the song (with the teacher singing, or with an audio recording or video).

From the three experts above, it looks they agree with the following steps of applying song media in teaching English language. (1) Teach the song line by line. (2) If there are multiple verses and a refrain, follow these steps: (a) each the refrain line by line, (b) teach the tune of the verse using "la la" instead of the lyrics (be sure to add the refrain with the lyrics at the end of the verse), (c) teach the verses one by one, always singing the refrain after each one. (3) Point 
out words that rhyme at the end of each line and practice repeating them when teaching each verse.

\section{METHOD}

The aim of this article is to know of implementation or steps applying song media in teaching English language that is used in Elementary School at third grade students in SDN Cibeber 1 Cimahi. For this subjects of the research are the students at third grade, their English teacher in SDN 1 Cibeber, and equipment related to the steps of implementing media song In this research the instrument consist of first writerselves and the second instrument used observation of paper. The writer analysis of the problems used as research materials using descriptive qualitative analysis used observation of paper. The data was taken when the teacher teach English learning in classroom used media song and to see steps implementation used by teacher with step which has been made by the writer with reference from the exeperts and then seen comparison whether it is appropriate or not. For the result implementation song media in SDN Cibeber 1 Cimahi, it measures that according to experts still less than half that should be filled.

As for the expert stated about the steps in the data analysis process, the writers also made the steps in doing field observation.

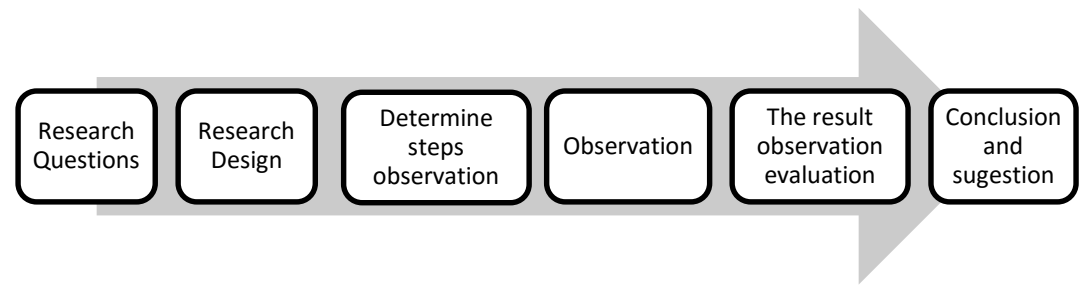

Figure 1:

Steps how to observe

The writers choose this method to describe implementation applying media song in class. Before the writers do the first analysis the writers divide the main terms of reference for the analysis, the second division of tasks in conducting the analysis, the third summarizes the results of the analysis as well as alternatives problem.

\section{RESULTS AND DISCUSSION}

Data were taken from fieldnotes the steps that have been made by the writers based on the reference from the experts. The data were implementation media song in learning English in the classroom. This observation in collecting data was conducted on Monday, February 26, 2018 at 11 am to $12 \mathrm{pm}$ precisely in third grade students in SDN 1Cibeber Cimahi.

After the data were collected, the writer did the analysis due to them, the analysis can briefly be explained as follows:

Listen to the song; It is the first steps of implementation in teaching media song along with according to experts and get results. Steps in teaching English with song: First, students write the questions given by the teacher, before the teacher play the song to the students more than one. But no text or scripts are provided. Second, teacher provides appropriate vocabulary 
(color). Third, the teacher dictated the song and the students repeated the song by pausing the song. The teacher played the song back. Fourth, the teacher asked the students to sing the song, but many of the students did not memorize it because the teacher did not give the song's text. Fifth, the teacher corrects the pronunciation and the meaning of the vocabulary after it is played and sings the song. Then, the teacher explains the questions previously given by the teacher. The last students do the problem by listening to the song first. In the result analysis, the teacher prepare speakers, laptop for equipment, captured song titled color and fruit then the teacher play the song as much as $2 \mathrm{x}$ ago. He is emphasizes the material more to color than to the fruit by teaching the way of listening, pronunciation, and writing. According to expert procedure used in learning media song is to listen to the song to make it easier for students to remember the vocabulary in the song.

Giving song text; According to expert procedure in learning media song is giving song text to know and expedite the students in understanding the contents of the song. It is the second steps of implementation in teaching media song along with according to experts and get results: The song is in use only one song but includes two themes of fruit and color, but more emphasis on color, duration of the song for 2 minutes. The teacher did not give the song text to the students, but gave a five-question evaluation about the material of the song as well as teacher do not prepare for the practice first, he immediately make a question when learning begins or suddenly in the absence of text song theirs do not understand what is being heard from the song, he should have text song for theirs to make it easier to sing and understand the contents of the song.

Teach the song line by line; Experts also mentioned that the next step in applying the media song that is teach the song line by line, related to it we can observe in the school is some different from the theory proposed by experts. Based on the research in teaching learning process the teacher playing the song with a few of the lyrics, so that students can catch the vocabulary who exist on the song. But the teacher doesn't doing song line by line in here just focus on the vocabulary who appropriate with the theme of which was taught in every song lyric, so that students do not be prosecuted to memorizing overall of the song. The teacher replay a few of the song aims to know or check pronunciation of the students said. The teacher should giving the text first and begin to singing in line by line and followed by all students so that students can follow in terms of understanding and pronunciation of the song. And related according to experts procedure in learning media song is teach the song line by line aims to facilitate the students in memorizing every lyric in the song.

Invite students to listen and repeat and practice; Analysis result at step teacher invite students to listen, repeat, and practice, the classroom teacher practice by pausing the song, then the students listen, after that students repeat the keywords in the song and the teacher appoints the students to repeat the existing keyword at the song. This is necessary for proper student pronunciation and training.

Display them together, individually, in group, in pairs; Analysis result at step, teacher only practice to all students, without sharing them in groups or in pairs. Teacher should need to share them in groups or pairs so that students learn to work with their friends. And given the matter of training to students, but because of problems made by teacher suddenly without preparation in advance, then the form of the problem less precise.

Refers to the purpose of the analysis to find out the steps in teaching the song media. The steps that can be taken from teachers who teach in the media song at SDN Cibeber 1 already have components and steps suit the experts. However, so there are something that need to be refined related in the steps of the teacher teaches from the five points that the author of the analysis, 
three points are not in accordance with the expert on the second point does not give the song text, third point in teach song line by line, and the last does not make a group.

This part convers the discussion of implementation song media in SDN Cibeber 1 Cimahi. The discussion is based on how to steps implement media song in the classroom with steps that has been made by the writers based on reference from the three experts.

The finding of the research proved that not fully in accordance with the should as has been put forward by the experts. The first steps appropriate with experts the teacher listen to the song it's important for make familiar the word for students. The second steps the teacher did not give the text song to students, maybe the teacher did not prepare of the text song so, the students just listen the song. Then the the next steps the teacher also did not teach line by line to students, he just play the song and mention what are they anything in the song focus on material not the song. Furthermore the steps the teacher invite the students listen and repeat and practice the song in this appropriate with experts and teacher too focus the pronunciation's students. The last steps teacher only practice to all students, without sharing them in groups or in pair, because he just focus of learning English for materials and pronunciation's students compared with the song. So the implementation song media in classroom got positive response from students and can make them fun, active learning English with media song.

After knowing from the result, three points are not in accordance with the expert on the second point does not give the song text, third point in teach song line by line, and the last does not make a group. Then the writers can conclude based on the similarity between the steps from the writers reference from experts and reality teacher apply media song in class used percentage, that is:

Table 1 The Result of the Analysis

\begin{tabular}{llcl}
\hline No & \multicolumn{1}{c}{ Accordance to expert } & Reality in class & \multicolumn{1}{c}{ Explantion } \\
\hline 1 & Listen to the song & $\checkmark$ & $\begin{array}{l}\text { On the steps similarly the } \\
\text { teacher and experts they apply } \\
\text { song first. It's important for } \\
\text { make familiar the word for } \\
\text { students. }\end{array}$ \\
\hline 2 & Giving song text & - & $\begin{array}{l}\text { According to expert is } \\
\text { important to give note/ script } \\
\text { song, but not in this steps. }\end{array}$ \\
\hline 3 & Teach song line by line & $\begin{array}{l}\text { That is no implementation } \\
\text { appropriate to the expert } \\
\text { because the teacher doesn't } \\
\text { prepared the paper. }\end{array}$ \\
\hline 4 & $\begin{array}{l}\text { Invite the students to listen and repeat and } \\
\text { practice }\end{array}$ & - & $\begin{array}{l}\text { The teacher appoints the } \\
\text { students to repeat the existing } \\
\text { keyword at the song. This is } \\
\text { necessary for proper student } \\
\text { pronunciation and training. }\end{array}$ \\
\hline 5 & $\begin{array}{l}\text { Display them together, individually, in group, in } \\
\text { pairs. }\end{array}$ & $\begin{array}{l}\text { Teacher only practice to all } \\
\text { students, without sharing them } \\
\text { in groups or in pairs. }\end{array}$ \\
\hline
\end{tabular}

The result on the table above that implementation song media in SDN Cibeber 1 Cimahi, it measures that according to experts still less than half that should be filled. 


\section{Conclusion}

Refers to the purpose of the analysis to find out the steps in teaching the song media. The steps that can be taken from teachers who teach in the media song at SDN Cibeber 1 already have components and steps suit the experts. However, so there are something that need to be refined related in the steps of the teacher teaches from the five points that the authors of the analysis, three points are not in accordance with the expert on the second point does not give the song text, third point in teach song line by line, and the last does not make a group.

After the authors observed in the school we can conclude before using media song the teacher must prepare in advance along with adequate facilities and infrastructure.

\section{REFERENCES}

Febriati, E. (2014). The Use of Song Lyrics to Improve Students' Vocabulary. cimahi: STKIP Siliwangi Bandung.

Janah, L. u. (2016). Penerapan Media Audio-Visual pada Mata Pelajaran Bahasa Inggris Kelas V di SD AL-Irsyad 01 Purwokerto. purwokerto: Institut Agama Islam Negeri (IAIN). Kaswan, \& Suprijadi, D. (2014). Second Language Acquisition. Bandung: Dapur Buku.

Keskin, F. (2011). Using Songs As Audio Material in Teaching Turkish as a Foreign Language. Nurhayati, L. (2002). Penggunaan Lagu dalam Pembelajaran Bahasa Inggris Untuk Siswa SD: Mengapa dan Bagimana.

Ratminingsih, N. M. (2014). Analisis potensi dan masalah MediaPembelajaran Bahasa Inggris di Sekolah Dasar.

Shin, J. K. (2014). Using Songs and Movement with Young Learners of English, 19. Sudjana, N., \& Rivai, A. (2015). Media Pembelajaran. Bandung: Sinar Baru Algensindo. Uno, H. D. (2006). Teori Motivasi dan Pengukurannya. Jakarta: PT Bumi Aksara. 